\title{
Yersinia similis sp. nov.
}

\author{
Lisa D. Sprague, ${ }^{1}$ Holger C. Scholz, ${ }^{2}$ Sabine Amann, ${ }^{3}$ H.-J. Busse ${ }^{3}$ \\ and Heinrich Neubauer ${ }^{1}$ \\ ${ }^{1}$ Friedrich-Loeffler-Institut, Naumburgerstr. 96a, D-07743 Jena, Germany \\ ${ }^{2}$ Bundeswehr Institut für Mikrobiologie, Abteilung für Bakteriologie, Neuherbergstr. 11, \\ D-80937 München, Germany \\ ${ }^{3}$ Institut für Bakteriologie, Mykologie und Hygiene, Veterinärplatz 1, A-1210 Wien, Austria
}

Correspondence

Lisa D. Sprague

natter13@gmx.de
On the basis of DNA-DNA hybridization, Yersinia pseudotuberculosis has been considered to be a molecularly homogeneous species (Brenner et al., 1976; Bercovier et al., 1980). Phenotypic characterization of $Y$. pseudotuberculosis strains by means of a sophisticated serotyping scheme (Tsubokura \& Aleksic, 1995; Nagano et al., 1997) and restriction endonuclease analysis of virulence plasmids (REAP), has discriminated pathogenic and non-pathogenic clones (Fukushima et al., 1998). Apart from European O:3 melibiose-negative strains, melibiose non-fermenters are only rarely found in other serogroups $(<0.5 \%$; Fukushima et al., 2001). A PCR assay targeting the $16 \mathrm{~S}$ rRNA gene of Yersinia pestis and $Y$. pseudotuberculosis reacted negatively when it was used on a number of strains phenotypically assigned to $Y$. pseudotuberculosis (Neubauer et al., 2000a). Several studies have demonstrated the applicability of $16 \mathrm{~S}$ rRNA gene sequence analysis for the identification of species within the genus Yersinia and its use to determine distinct species-specific markers, for example for Yersinia aleksiciae and Yersinia enterocolitica subsp. enterocolitical Yersinia enterocolitica subsp. palearctica (Ibrahim et al., 1993; Neubauer et al., 2000b; Sprague \& Neubauer, 2005). The aim of the present study was to investigate whether

The GenBank/EMBL/DDBJ accession numbers for the 16S rRNA gene sequences of strains Y36, ATCC $29833^{\top}, Y_{117}, Y_{228}^{\top}, Y 233$ and Y252 are AM182400, AM182401, AM182402, AM182404, AM182405 and AM182406, respectively.

A supplementary table detailing DNA-DNA hybridization values between strains of Yersinia pseudotuberculosis and strains $Y_{228}{ }^{\top}$, Y233 and Y252 is available with the online version of this paper. isolates of $Y$. pseudotuberculosis displaying different $16 \mathrm{~S}$ rRNA gene sequences could be classified as representatives of a novel species.

Six Yersinia isolates that had been originally phenotyped as $Y$. pseudotuberculosis by the former German Yersinia Reference Centre, Hamburg, Germany, were extensively investigated by molecular and biochemical techniques (Tables 1 and 2). Type strains were purchased from the ATCC, Rockville, Maryland, USA, with the exception of $Y$. enterocolitica subsp. palearctica $\mathrm{Y}_{11}^{\mathrm{T}}\left(=\mathrm{DSM} 13030^{\mathrm{T}}\right)$. Other type strains of species of the genus Yersinia included in the study were $Y$. pseudotuberculosis ATCC $29833^{\mathrm{T}}$, Yersinia ruckeri $\mathrm{Y}^{\mathrm{T}} \mathrm{T}^{\mathrm{T}}\left(=\mathrm{ATCC} 29473^{\mathrm{T}}\right)$ and Yersinia kristensenii $\mathrm{Y}_{110^{\mathrm{T}}}\left(=\mathrm{ATCC} 33638^{\mathrm{T}}\right)$. Strains were maintained on standard nutrient agar I (Oxoid) at $4{ }^{\circ} \mathrm{C}$. Subcultivation was performed on blood agar overnight at $28^{\circ} \mathrm{C}$. Broth culture was carried out overnight in LuriaBertani medium (Difco) at $28{ }^{\circ} \mathrm{C}$ and 150 r.p.m. in controlled environment shakers (New Brunswick). Cells were harvested by centrifugation ( $1200 \mathrm{~g}$ for $30 \mathrm{~min}$ ) and stored in $70 \%$ 2-propanol at $4{ }^{\circ} \mathrm{C}$ until used for DNADNA hybridization experiments.

Chemotaxonomic analyses were carried out with strain $\mathrm{Y} 228^{\mathrm{T}}, Y$. enterocolitica subsp. palearctica $\mathrm{Y}_{1} 1^{\mathrm{T}}$ and $Y$. pseudotuberculosis ATCC $29833^{\mathrm{T}}$. The strains were grown on $3.3 \times$ PYE [ $1 \%$ peptone from casein (Roth); $1 \%$ yeast extract (Merck), pH 7.2] and polyamines were extracted and analysed as described by Busse \& Auling (1988) and Stolz et al. (2007). Quinone systems and polar lipids were 
Table 1. Characterization of the Yersinia isolates examined in this study

ND, Not determined; P, 16S rRNA gene sequence type of Y. pseudotuberculosis ATCC $29833^{\mathrm{T}}$; S, $16 \mathrm{~S}$ rRNA gene sequence type of strain Y228 ${ }^{\mathrm{T}}$. The P and S $16 \mathrm{~S}$ rRNA gene sequence types are characterized by the following specific sequence markers: P, 5' -ATTTGGCAGAGATGCTAAA-3'; S, 5' GATTTGGCAGAGATGCCTTA-3' (Neubauer et al., 2000a). None of the isolates tested positive for the presence of the plasmid fixed pathogenicity marker adhesin gene (Neubauer et al., 2000c).

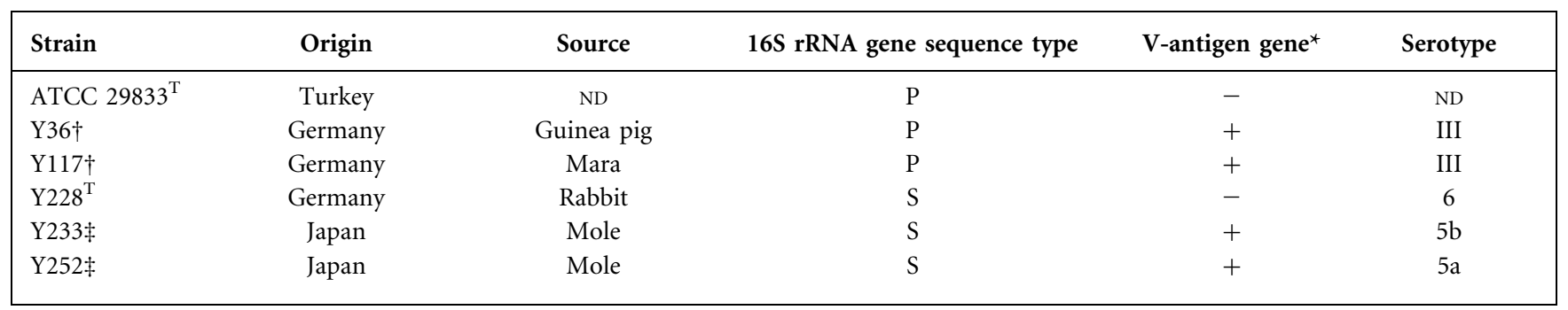

${ }^{\star}$ Presence of the chromosomally fixed pathogenicity marker V-antigen (Neubauer et al., 2000c).

$†$ Supplied by Dr G. Wolf, LMU, Faculty of Veterinary Medicine, Munich, Germany.

$\ddagger$ Supplied by Professor Dr S. Aleksic, formerly German National Reference Laboratory for Yersiniosis, Hamburg, Germany.

analysed according to the procedures of Tindall (1990a, b) and Altenburger et al. (1996) using HPLC apparatus as described by Stolz et al. (2007). Molecular and biochemical characterization and identification of Yersinia isolates was conducted as described by Neubauer et al. (2000a, b, c). Multiple sequence alignments of partial 16S rRNA gene sequences were performed with CLUSTAL $\mathrm{W} 1.8$ and with BOXSHADE 3.21 (available at http://clustalw.genome.jp/ and http://www.ch.embnet.org/software/BOX_form.html).

The phylogenetic tree based on rrs gene sequences (1388 nt) was generated using the online accessible bioinformatics tools from HUSAR (available from http://genius. embnet.dkfz-heidelberg.de/menu/w2h/w2hdkfz). The $r$ rs gene sequences were aligned using CLUSTAL w. The phylogenetic tree was constructed from the alignment obtained with CLUSTREE and the Kimura two-parameter model was implemented. Phylogenetic reconstruction was conducted using the neighbour-joining method and 1000 bootstrap resamplings were performed to assess the probabilities of the nodes. Trees were rooted using the 16S rRNA gene sequence of Escherichia coli ATCC 43895.

The API 20E (bioMérieux) test was performed as described by the manufacturer and the semi-miniaturized Yersinia identification system (Merlin) was used according to Neubauer et al. (2000d). All incubations were carried out at $28{ }^{\circ} \mathrm{C}$ in order to avoid the failure of metabolic reactions that can occur at $37{ }^{\circ} \mathrm{C}$. DNA extractions, DNA-DNA hybridizations and determination of the $\mathrm{G}+\mathrm{C}$ contents were carried out at the Deutsche Sammlung von Mikroorganismen und Zellkulturen (DSMZ), Braunschweig, Germany, as recently described (De Ley et al., 1970; Cashion et al., 1977; Escara \& Hutton, 1980; Huß et al., 1983; Tamaoka \& Komagata, 1984; Mesbah et al., 1989; Jahnke, 1992; Martin et al., 1997).

All of the putative $Y$. pseudotuberculosis strains were small, Gram-negative, motile coccoid rods and were catalase- and urease-positive and oxidase-negative. The strains were positive in tests for rhamnose, glucose, trehalose and Lpyroglutamic acid- $\beta$-naphthylamide and showed various negative reactions (Table 2). Strains ATCC $29833^{\mathrm{T}}$, Y117 and $\mathrm{Y} 36$ all possessed 16S rRNA gene sequence type $\mathrm{P}$ and were able to ferment melibiose. By the use of a semiminiaturized Yersinia identification system (Merlin) optimized for Yersinia isolates, these strains were clearly identified as $Y$. pseudotuberculosis with a relative probability of $100 \%$ and an absolute probability of $<1200: 1$. Strains $\mathrm{Y}_{228^{\mathrm{T}}}$, Y252 and Y233 all possessed 16S rRNA gene sequence type $S$ and were melibiose-negative. These strains were also identified as $Y$. pseudotuberculosis with a relative probability of $>95 \%$ but with an absolute probability of $>10000: 1$, making this diagnosis doubtful (Neubauer et al., 2000d). The API 20E test system identified all six strains as $Y$. pseudotuberculosis. The type strain of $Y$. pseudotuberculosis, ATCC $29833^{\mathrm{T}}$, was negative for tryptophan deaminase and gelatin. However, it showed a number of very untypical reactions when compared with the majority of strains belonging to the species $Y$. pseudotuberculosis by using the semi-miniaturized Yersinia identification system, i.e. aesculin, cellobiose, lactose, sorbose and the Voges-Proskauer reaction (Sprague \& Neubauer, 2005). In the classical tube testing system, no deviations were observed from the original species description (Bercovier et al., 1980). The anomalous results seen in the semi-miniaturized Yersinia identification system can be explained by the formulation of the reagents and the arbitrary choice of cut-off values selected for optimal species and biovar designation within the genus Yersinia or Yersinia enterocolitica, respectively (Neubauer et al., $2000 \mathrm{~d}$ ). Additionally, positive reactions were observed for $\gamma$-glutamyl- $\beta$-naphthylamide, L-pyroglutamic acid- $\beta$ naphthylamide and proline, but negative reactions were observed for $\mathrm{p}$-nitrophenyl- $\beta$-D-xylopyranoside, $\mathrm{p}$-nitrophenyl- $\beta$-glucuronide, 5 -bromo-4-chloro-3-indolyl butyrate and pyracinamidase. 
Table 2. Biochemical characterization of strains of $Y$. pseudotuberculosis and the proposed species Yersinia similis sp. nov. compared with biochemical patterns of other type strains of the genus Yersinia (Table modified according to Sprague \& Neubauer, 2005)

Taxa: 1, Y. mollaretii; 2, Y. aldovae; 3, Y. bercovieri; 4, Y. intermedia; 5, Y. rhodei; 6, Y. enterocolitica subsp. enterocolitica; 7, Y. enterocolitica subsp. parlearctica; 8, Y. aleksiciae; 9, Y. frederiksenii; 10, Y. kristensenii; 11, Y. pestis $(n=40)$; 12, Y. pseudotuberculosis ( $n=36$; data from Neubauer et al., 2000d); 13, Y. similis sp. nov. ( $\mathrm{n}=3$ ); 14, Y. similis sp. nov. strain Y228 ${ }^{\mathrm{T}}$; 15, Y233; 16, Y252; 17, Y. ruckeri. +, Positive; -, negative. Values for taxa 11-13 are \% positive reactions for the group of strains. All taxa gave negative results for $\mathrm{H}_{2} \mathrm{~S}$, for the fermentation of amygdalin, dulcitol and inulin, and for the activities of arginine dihydrolase, $\mathrm{p}$-nitrophenol- $\beta$-glucuronide, pyracinamidase and tryptophan deaminase. All taxa gave positive results for fermentation of glucose.

\begin{tabular}{|c|c|c|c|c|c|c|c|c|c|c|c|c|c|c|c|c|c|}
\hline Characteristic & 1 & 2 & 3 & 4 & 5 & 6 & 7 & 8 & 9 & 10 & 11 & 12 & 13 & 14 & 15 & 16 & 17 \\
\hline \multicolumn{18}{|l|}{ Fermentation of: } \\
\hline Adonitol & - & - & - & - & - & - & - & - & - & - & 0 & 6 & 0 & - & - & - & - \\
\hline Cellobiose & + & + & + & + & + & + & - & + & + & + & 0 & 0 & 0 & - & - & - & - \\
\hline D-Xylose & + & + & + & + & + & + & - & + & + & + & 10 & 94 & 100 & + & + & + & - \\
\hline Glycerine & + & - & - & + & + & + & + & + & + & + & 0 & 89 & 100 & + & + & + & + \\
\hline Lactose & - & + & + & - & - & - & - & - & - & - & 0 & 0 & 33 & + & - & - & - \\
\hline Melibiose & - & + & - & + & + & - & - & - & - & - & 0 & 97 & 0 & - & - & - & - \\
\hline Raffinose & - & - & - & - & + & - & - & - & - & - & 0 & 0 & 0 & - & - & - & - \\
\hline Rhamnose & - & + & - & + & - & - & - & - & + & - & 0 & 100 & 100 & + & + & + & - \\
\hline Salicin & - & - & + & + & + & - & - & - & + & - & 0 & 11 & 0 & - & - & - & - \\
\hline Sorbitol & + & + & + & + & + & + & + & + & + & + & 0 & 0 & 0 & - & - & - & - \\
\hline Aesculin & - & - & + & + & + & - & - & - & + & - & 100 & 94 & 100 & + & + & + & - \\
\hline Citrate & + & + & - & + & + & - & + & - & + & - & 5 & 0 & 0 & - & - & - & - \\
\hline Indole & - & - & - & + & - & + & - & + & + & + & 0 & 0 & 0 & - & - & - & - \\
\hline L-Proline- $\beta$-naphthylamide & + & + & + & + & + & - & - & + & + & + & 73 & 100 & 0 & - & - & - & + \\
\hline L-Pyroglutamic acid- $\beta$-naphthylamide & + & + & + & + & + & + & + & + & + & + & 0 & 100 & 100 & + & + & + & + \\
\hline Lysine decarboxylase & - & - & - & - & - & - & - & + & - & - & 0 & 0 & 0 & - & - & - & - \\
\hline Malonate & - & - & - & - & - & - & + & - & - & - & 5 & 0 & 0 & - & - & - & - \\
\hline o-Nitrophenyl- $\beta$-D-galactopyranoside & + & - & + & + & + & + & + & + & + & + & 0 & 75 & 0 & - & - & - & + \\
\hline o-Nitrophenyl- $\beta$-D-xylopyranoside & - & - & - & - & + & - & - & - & - & - & 0 & 0 & 0 & - & - & - & - \\
\hline Ornithine decarboxylase & + & + & + & + & + & + & + & + & + & + & 0 & 0 & 0 & - & - & - & + \\
\hline
\end{tabular}

Chemotaxonomic analyses (Table 3 ) revealed rather similar polyamine patterns for strains $\mathrm{Y} 228^{\mathrm{T}}, \mathrm{Y}_{11}{ }^{\mathrm{T}}$ and ATCC $29833^{\mathrm{T}}$ with putrescine as the predominant compound. Moderate to minor amounts of spermidine and minor amounts of 1,3-diaminopropane and spermine were detected in the three strains. Only Y. enterocolitica subsp. palearctica $\mathrm{Y}_{11}{ }^{\mathrm{T}}$ tested positive for the presence of cadaverine. The presence of cadaverine in the polyamine pattern of the type strain of $Y$. enterocolitica subsp. palearctica is in agreement with the results from a previous report (Hamana, 1996) where cadaverine was found to be the predominant compound. This difference could be caused by the use of different media for the growth of biomass. Another explanation for the difference might be that Hamana (1996) harvested cells that were either growing exponentially or were at the stationary phase, whereas in this study cells were harvested at approximately $70 \%$ of the maximum optical density.

Ubiquinone Q-8 was the predominant quinone compound found in the three strains $\left(\mathrm{Y}_{22} 28^{\mathrm{T}}, \mathrm{Y}_{11}^{\mathrm{T}}\right.$ and ATCC $29833^{\mathrm{T}}$ ). Additionally, minor amounts of Q-9 and minor to moderate amounts of menaquinone MK-8 were detected. Similar quinone systems have been reported for all species of the family Enterobacteriaceae examined so far (Yokota et al., 1992). The polar lipid profile of strain Y228 ${ }^{\mathrm{T}}$ shared major characteristics with the other two strains (Table 3), but could be distinguished from Y. pseudotuberculosis ATCC $29833^{\mathrm{T}}$ due to the lack of phosphatidylmonomethylethanolamine and two aminolipids. The 
Table 3. Chemotaxonomic characteristics of strain $\mathrm{Y}_{228^{\top}}$ and the type strains of two Yersinia reference species

Components in the polyamine patterns and quinone systems are given in relative amounts (\%). All taxa had major amounts of phosphatidylethanolamine (PE) and diphosphatidylglycerol (DPG) and moderate amounts of phosphatidylglycerol (PG). ++ , Present in moderate amounts; + , present in minor amounts; ND, not detected; PME, phosphatidylmonomethylethanolamine; APL1, unknown aminophospholipid; AL1, AL2, unknown amino lipids.

\begin{tabular}{|c|c|c|c|}
\hline Strain & $\mathrm{Y}^{228^{\mathrm{T}}}$ & $\begin{array}{l}\text { Y. enterocolitica } \\
\text { subsp. palearctica } \\
\text { DSM } 13030^{\mathrm{T}}\end{array}$ & $\begin{array}{c}Y . \\
\text { pseudotuberculosis } \\
{\text { ATCC } 29833^{\mathrm{T}}}^{\text {ATC }}\end{array}$ \\
\hline \multicolumn{4}{|l|}{ Polyamines } \\
\hline $\begin{array}{l}\text { 1,3-diamino- } \\
\text { propane }\end{array}$ & 0.9 & 1.8 & 0.3 \\
\hline Putrescine & 91.8 & 94.2 & 88.0 \\
\hline Cadaverine & ND & 2.6 & ND \\
\hline Spermidine & 6.4 & 1.3 & 11.4 \\
\hline Spermine & 0.9 & 0.2 & 0.3 \\
\hline \multicolumn{4}{|l|}{ Quinones } \\
\hline Q-8 & 89 & 95 & 93 \\
\hline Q-9 & 1 & 1 & 1 \\
\hline MK-8 & 10 & 4 & 6 \\
\hline \multicolumn{4}{|l|}{ Polar lipids } \\
\hline PME & ND & $\mathrm{ND}$ & + \\
\hline APL1 & ++ & ++ & ++ \\
\hline AL1 & ND & ND & + \\
\hline AL2 & ND & ND & + \\
\hline
\end{tabular}

chemotaxonomic characteristics of strain ATCC $29833^{\mathrm{T}}$ were in agreement with those of the two reference strains analysed in this study and thus support the assignment of this strain to the genus Yersinia. Differences in the polar lipid profile (absence of phosphatidylmonomethylethanolamine and two aminolipids) compared with that of $Y$. pseudotuberculosis ATCC $29833^{\mathrm{T}}$ support the view that strain $\mathrm{Y} 228^{\mathrm{T}}$ is a representative of a novel species not yet described within the genus (Fig. 1).

All strains investigated gave a negative result in the plasminogen activator and F1 antigen gene PCR assay specific for Yersinia pestis. The 16S rRNA gene sequence type $S$ strains were negative in the $Y$. pseudotuberculosis/Y. pestis-specific $16 \mathrm{~S}$ rRNA gene PCR described by Neubauer et al. due to sequence alterations in the sequence of primer PT2 (Neubauer et al., 2000a). Molecular pathogenicity markers were dispersed within all strains investigated (Table 1). A phylogenetic tree constructed from the 16S rRNA gene sequence obtained from this study and the sequences of the type strains of all the other recognized species of the genus Yersinia showed the close relatedness of $Y$. pestis and Y. pseudotuberculosis. The Y. pseudotuberculosis-like strains of $16 \mathrm{~S}$ rRNA gene type $\mathrm{S}$ uniformly grouped into their own cluster (Fig. 2).

Strains possessing $16 \mathrm{~S}$ rRNA gene sequence type $\mathrm{P}$ (strains Y36, ATCC $29833^{\mathrm{T}}$ and Y117) formed a genomic species

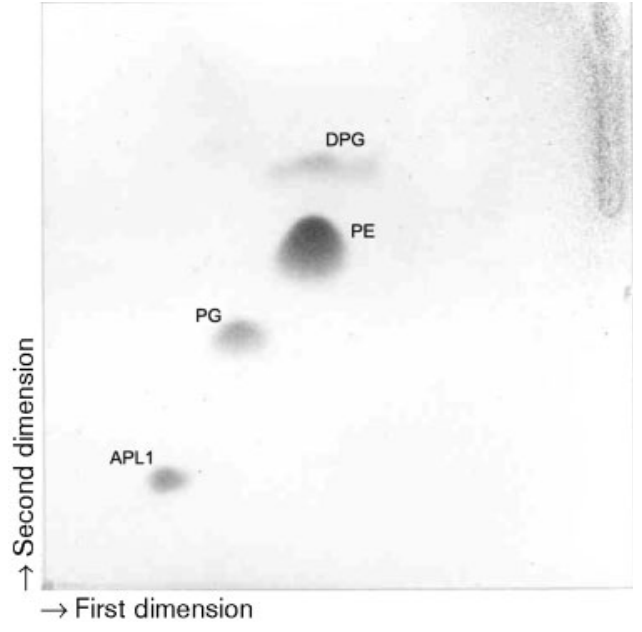

Fig. 1. Two-dimensional TLC of polar lipids of strain $Y 228^{\top}$. For abbreviations see Table 3 .

with an intragroup relatedness of $>70 \%$ DNA-DNA relatedness. Hence, we consider only strains Y36 and Y117 to represent the species $Y$. pseudotuberculosis. It has to be stressed that this sequence type can also be found in the $16 \mathrm{~S}$ rRNA genes of other bacteria. As a marker for $Y$. pseudotuberculosis, it can only be used after an isolate has already been phenotypically assigned to the genus Yersinia. Strains of $16 \mathrm{~S}$ rRNA gene sequence type S (strains $\mathrm{Y} 228^{\mathrm{T}}$, Y233 and Y252) formed a second genomic species with an intragroup relatedness of $>70 \%$ DNA-DNA relatedness, but only 44-66\% relatedness with strains of Y. pseudotuberculosis (see Supplementary Table S1 available in IJSEM Online). Members of these genomic species showed no significant degree of DNA-DNA relatedness to Y. ruckeri ATCC $29473^{\mathrm{T}}$ or Y. kristensenii ATCC $33638^{\mathrm{T}}$ (see Supplementary Table S1). The G+C contents of the DNA for strains Y36, Y117, Y228 ${ }^{\mathrm{T}}$, Y233 and Y252 were $48.9 \mathrm{~mol} \%, \quad 48.9 \mathrm{~mol} \%, \quad 48.1 \mathrm{~mol} \%, \quad 47.6 \mathrm{~mol} \%$ and $49.3 \mathrm{~mol} \%$, respectively. Strains characterized by the lack of melibiose utilization and a $16 \mathrm{~S}$ rRNA sequence of type $S$ were considered to represent a separate novel species, referred from now on as Yersinia similis sp. nov.

Y. similis sp. nov. strains showed a high sequence similarity in helix 18 of the 16S rRNA gene sequence [positions 451480 according to $E$. coli $16 \mathrm{~S}$ rRNA International Union of Biochemistry (IUB) nomenclature] to the gene sequences of $Y$. pestis and Y. pseudotuberculosis. 16S rRNA gene sequences have already been used as markers to identify novel species and subspecies within the genus Yersinia (Neubauer et al., 2000b; Sprague \& Neubauer, 2005). Thus, in order to differentiate $Y$. similis sp. nov., a new specific sequence 5'-GATTTGGCAGAGATGCCTTA-3' (positions 987-1006; E. coli IUB nomenclature) is proposed as a suitable genetic marker. The phenotypic marker for the biochemical differentiation of $Y$. pseudotuberculosis and $Y$. similis sp. nov. is melibiose fermentation which is regularly 


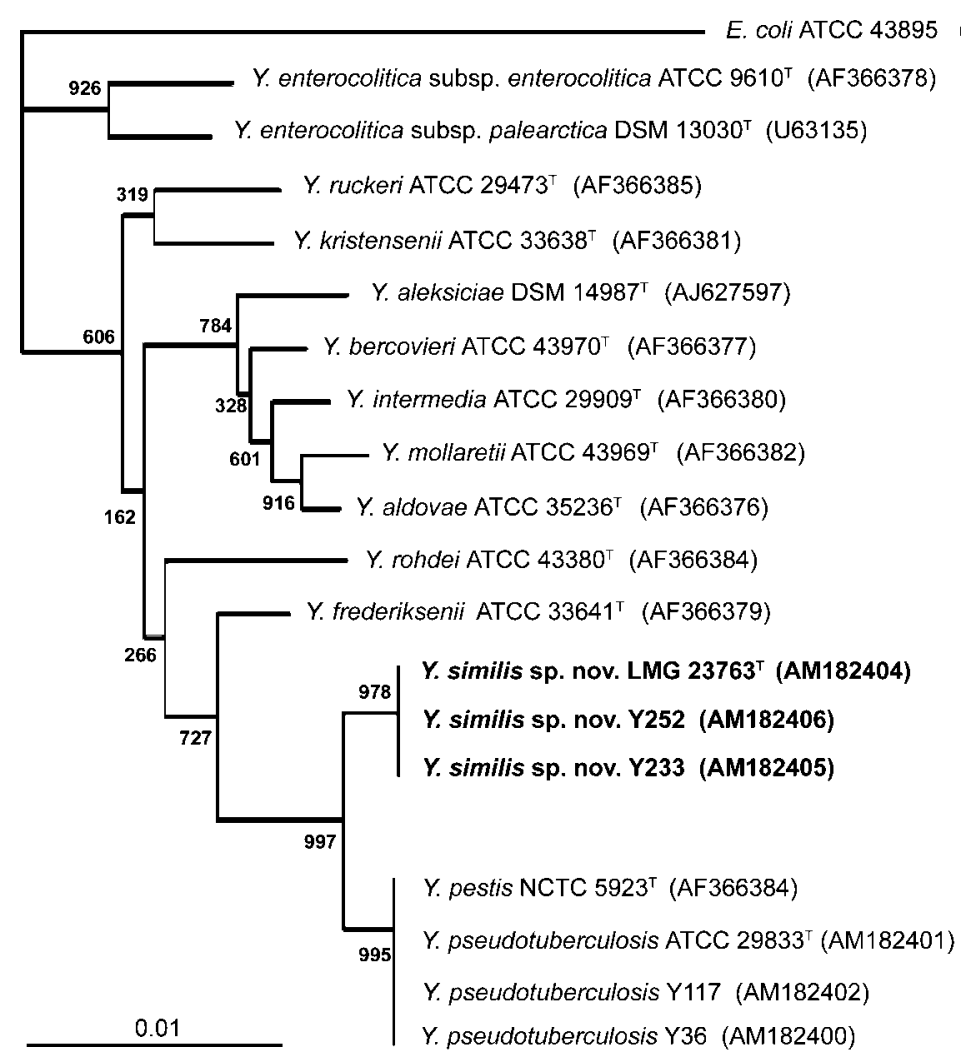

(Z83205)

\begin{abstract}
Fig. 2. Phylogenetic tree obtained with $16 \mathrm{~S}$ rRNA gene sequences (1388 nt) using CLUSTREE neighbour-joining analysis. The significance of each branch is indicated by a bootstrap value calculated for 1000 subsets. The tree was rooted with the outgrouping sequence of $E$. coli ATCC 43895 (GenBank accession no. Z83205). Bar, 0.01 divergent residues per site.
\end{abstract}

observed for $Y$. pseudotuberculosis but not for $Y$. similis $\mathrm{sp}$. nov. However, sporadically melibiose-negative strains of $Y$. pseudotuberculosis have been described previously (Fukushima et al., 2001). The strains of Y. similis sp. nov. investigated in this study appear to belong to the nonpathogenic, virulence-plasmidless genetic group 4 as described by Fukushima et al. (2001). The strains have been isolated from animals with clinically inapparent infections and from the environment, i.e. surface water, but have never been isolated from diseased animals or humans. The occurrence of strains such as $Y$. similis $\mathrm{sp}$. nov. Y $228^{\mathrm{T}}$ in Germany is not surprising as strains of the genus Yersinia can be easily introduced into non-endemic areas via food, animals or even human travellers (Fukushima et al., 2001).

A molecular subgroup within Y. pseudotuberculosis strains (subgroup 4) was identified by Kim et al. (2003) by $16 \mathrm{~S}$ rRNA gene sequencing, REP-PCR, ERIC-PCR and BoxPCR. This subgroup was made up of strains of our $16 \mathrm{~S}$ rRNA gene sequence type $S$ (GenBank accession nos AF 365936, AF365945, AF365948 and AF365950) of serotypes 1c, 6, 9 and 11. These strains can now also be identified as $Y$. similis sp. nov. Strains of $Y$. similis sp. nov. should be grouped into risk class 2 until non-pathogenicity for man has been confirmed.

The 16S rRNA gene sequences of the three $Y$. similis sp. nov. strains were identical (Fig. 2), exhibiting $99.6 \%$ similarity with the $16 \mathrm{~S}$ rRNA gene sequences of $Y$. pseudotuberculosis and Y. pestis. When comparing the $16 \mathrm{~S}$ rRNA gene sequences of the type strains of the species of the genus Yersinia, the sequence similarity never falls below $97.4 \%$.

The mean $\mathrm{G}+\mathrm{C}$ content of the DNA of the Y. pseudotuberculosis isolates was $48.4 \mathrm{~mol} \%$ and is thus $1.9 \mathrm{~mol} \%$ above the previously published value (Bercovier et al., 1980). The mean $\mathrm{G}+\mathrm{C}$ content of the DNA of $Y$. similis sp. nov. is estimated to be $48.3 \mathrm{~mol} \%$. This value is slightly higher than the values determined for $Y$. pseudotuberculosis strain IP32953 (47.55 mol\%) and several strains of $Y$. pestis (47.63-47.70 mol\%) based on their whole genome sequences (http://cmr.tigr.org/tigr-scripts/CMR/shared/ Genomes.cgi) and $1.8 \mathrm{~mol} \%$ higher than the value published for Y. pseudotuberculosis (Bercovier \& Mollaret, 1984). This estimate is within the accepted limits for the genus Yersinia of 46-50 mol\% (Bercovier \& Mollaret, 1984).

The 16S rRNA gene sequence type analysis, the results from DNA-DNA hybridizations, the absence of fermentation of melibiose and p-nitrophenyl- $\beta$-D-galactopyranoside and the absence of phosphatidylmonomethylethanolamine and two unknown aminolipids provide evidence that strains $\mathrm{Y} 228^{\mathrm{T}}$, Y233 and Y252 are representatives of a novel species which is phenotypically distinguishable from its nearest phylogenetic neighbour $Y$. pseudotuberculosis. The name $Y$. similis sp. nov. is proposed for these three isolates.

The importance of this novel species for ecologists, evolutionary geneticists and clinical microbiologists must 
be emphasized. Members of the novel species seem to be well adapted to the environment and do not cause disease. Y. similis sp. nov. is distributed in the Far East and in areas where plague is still endemic. Y. similis may therefore interfere with classical field diagnostics. The removal of this novel species from the $Y$. pestis/Y. pseudotuberculosis complex will also be an important step for future pathogenicity and evolution studies.

\section{Description of Yersinia similis sp. nov.}

Yersinia similis (si'mi.lis. L. fem. adj. similis similar, resembling, as the strains are similar to those of $Y$. pseudotuberculosis).

Cells are small, Gram-negative and motile coccoid rods. Cells are catalase- and urease-positive, oxidase-negative and reduce nitrate. Rhamnose-, trehalose- and glycinepositive, but melibiose-negative. The specific $16 \mathrm{~S}$ rRNA gene sequence marker is $5^{\prime}$-GATTTGGCAGAGATGCCTTA-3' (position 987-1006; E. coli IUB nomenclature). Other characteristics are listed in Tables 2 and 3. The mean DNA $\mathrm{G}+\mathrm{C}$ content is $48.3 \mathrm{~mol} \%$ (HPLC). The DNA $\mathrm{G}+\mathrm{C}$ content of the type strain is $48.1 \mathrm{~mol} \%$.

The type strain, Y228 ${ }^{\mathrm{T}}\left(=\right.$ CCUG $\left.52882^{\mathrm{T}}=\mathrm{LMG} 23763^{\mathrm{T}}\right)$, was isolated from a rabbit in Germany.

\section{Acknowledgements}

The excellent technical assistance of C. Lodri and R. Schneider is gratefully acknowledged. The work of S. A. and H.-J. B. was supported by a Contract-Research-Project for the Bundeswehr Medical Service.

\section{References}

Altenburger, P., Kämpfer, P., Makristathis, A., Lubitz, W. \& Busse, H.-J. (1996). Classification of bacteria isolated from a medieval wall painting. J Biotechnol 47, 39-52.

Bercovier, H. \& Mollaret, H. H. (1984). Genus XIV. Yersinia. In Bergey's Manual of Systematic Bacteriology, Vol. 1, pp. 498-506. Edited by N. R. Krieg \& J. G. Holt. Baltimore, MD: Williams and Wilkins.

Bercovier, H., Mollaret, H. H., Alonso, J. M., Brault, J., Fanning, G. R., Steigerwaldt, A. G. \& Brenner, D. J. (1980). Intra- and interspecies relatedness of Yersinia pestis by DNA hybridization and its relatedness to Yersinia pseudotuberculosis. Curr Microbiol 4, 225-229.

Brenner, D. J., Steigerwaldt, A. G., Falcao, D. P., Weaver, R. E. \& Fanning, G. R. (1976). Characterisation of Yersinia entercolitica and Yersinia pseudotuberculosis by deoxyribonucleic acid hybridization and by biochemical reactions. Int J Syst Bacteriol 26, 180-194.

Busse, H.-J. \& Auling, G. (1988). Polyamine pattern as a chemotaxonomic marker within the Proteobacteria. Syst Appl Microbiol 11, 1-8.

Cashion, P., Holder-Franklin, M. A., McCully, J. \& Franklin, M. (1977). A rapid method for the base ratio determination of bacterial DNA. Anal Biochem 81, 461-466.

De Ley, J., Cattoir, H. \& Reynaerts, A. (1970). The quantitative measurement of DNA hybridization from renaturation rates. Eur $J$ Biochem 12, 133-142.
Escara, J. F. \& Hutton, J. R. (1980). Thermal stability and renaturation of DNA in dimethyl sulfoxide solutions: acceleration of the renaturation rate. Biopolymers 19, 1315-1327.

Fukushima, H., Gomyoda, M., Hashimoto, N., Takashima, I., Shubin, F. N., Isachikova, L. M., Paik, I. K. \& Zheng, X. B. (1998). Putative origin of Yersinia pseudotuberculosis in western and eastern countries. A comparison of restriction endonuclease analysis of virulence plasmids. Zentralbl Bakteriol 288, 93-102.

Fukushima, H., Matsuda, Y., Seki, R., Tsubokura, M., Takeda, N., Shubin, F. N., Paik, I. K. \& Zheng, X. B. (2001). Geographical heterogeneity between Far Eastern and Western countries in prevalence of the virulence plasmid, the superantigen Yersinia pseudotuberculosis-derived mitogen, and the high-pathogenicity island among Yersinia pseudotuberculosis strains. J Clin Microbiol 39, 3541-3547.

Hamana, K. (1996). Distribution of diaminopropane and acetylspermidine in Enterobacteriaceae. Can J Microbiol 42, 107-114.

Huß, V. A. R., Festl, H. \& Schleifer, K. H. (1983). Studies on the spectrophotometric determination of DNA hybridization from renaturation rates. Syst Appl Microbiol 4, 184-192.

Ibrahim, A., Goebel, B. M., Liesack, W., Griffiths, M. \& Stackebrandt, E. (1993). The phylogeny of the genus Yersinia based on 16S rRNA sequences. FEMS Microbiol Lett 114, 173-178.

Jahnke, K. D. (1992). BASIC computer program for evaluation of spectroscopic DNA renaturation data from GILFORD SYSTEM 2006 spectrophotometer on a PC/XT/AT type personal computer. J Microbiol Methods 15, 61-73.

Kim, W., Song, M. O., Song, W., Kim, K. J., Chung, S. I., Choi, C. S. \& Park, Y. H. (2003). Comparison of $16 \mathrm{~S}$ rDNA analysis and rep-PCR genomic fingerprinting for molecular identification of Yersinia pseudotuberculosis. Antonie van Leeuwenhoek 83, 125-133.

Martin, K., Schumann, P., Rainey, F. A., Schuetze, B. \& Groth, I. (1997). Janibacter limosus gen. nov., sp. nov., a new actinomycete with meso-diaminopimelic acid in the cell wall. Int J Syst Bacteriol 47, 529-534.

Mesbah, M., Premachandran, U. \& Whitman, W. (1989). Precise measurement of the $\mathrm{G}+\mathrm{C}$ content of deoxyribonucleic acids by highperformance liquid chromatography. Int J Syst Bacteriol 39, 159-167.

Nagano, T., Kiyohara, T., Suzuki, K., Tsubokura, M. \& Otsuki, K. (1997). Identification of pathogenic strains within serogroups of Yersinia pseudotuberculosis and the presence of non-pathogenic strains isolated from animals and the environment. J Vet Med Sci 59, 153-158.

Neubauer, H., Meyer, H., Prior, J., Aleksic, S., Hensel, A. \& Splettstösser, W. (2000a). A combination of different polymerase chain reaction (PCR) assays for the presumptive identification of Yersinia pestis. J Vet Med B Infect Dis Vet Public Health 47, 573-580.

Neubauer, H., Hensel, A., Aleksic, S., Finke, E.-J. \& Meyer, H. (2000b). Yersinia enterocolitica 16S rRNA gene types belong to the same genospecies but form three different homology clusters. Int $J$ Med Microbiol 290, 61-64.

Neubauer, H., Sprague, L. D., Hensel, A., Aleksic, S. \& Meyer, H. (2000c). Specific detection of plasmid bearing Yersinia isolates by PCR. Clin Lab 46, 583-587.

Neubauer, H., Molitor, M., Rahalison, L., Aleksic, S., Backes, H., Chanteau, S. \& Meyer, H. (2000d). A semi-automated system for identification of Yersinia species within the genus Yersinia. Clin Lab 46, 561-567.

Sprague, L. D. \& Neubauer, H. (2005). Yersinia aleksiciae sp. nov. Int J Syst Evol Microbiol 55, 831-835.

Stolz, A., Busse, H.-J. \& Kämpfer, P. (2007). Pseudomonas knackmussii sp. nov. Int J Syst Evol Microbiol 57, 572-576. 
Tamaoka, J. \& Komagata, K. (1984). Determination of DNA base composition by reversed-phase high-performance liquid chromatography. FEMS Microbiol Lett 25, 125-128.

Tindall, B. J. (1990a). A comparative study of the lipid composition of Halobacterium saccharovorum from various sources. Syst Appl Microbiol 13, 128-130.

Tindall, B. J. (1990b). Lipid composition of Halobacterium lacusprofundi. FEMS Microbiol Lett 66, 199-202.
Tsubokura, M. \& Aleksic, S. (1995). A simplified antigenetic scheme for serotyping of Yersinia pseudotuberculosis: phenotypic characterisation of reference strains and preparation of $\mathrm{O}$ and $\mathrm{H}$ factor sera. Contrib Microbiol Immunol 13, 99-105.

Yokota, A., Akagawa-Matsushita, M., Hiraishi, A., Katayama, Y., Urakami, T. \& Yamasato, K. (1992). Distribution of quinone systems in microorganisms: Gram-negative eubacteria. Bull JFCC $\mathbf{8}$, 136-171. 